\title{
Biomedyczne problemy początków życia
}

Rozwijające się możliwości techniczne oraz związane z tym ludzkie dążenia i potrzeby powodują też wiele znaków zapytania i wątpliwości, a nawet jednoznacznych sprzeciwów natury etyczno-moralnej. Potrzeba poszukiwania odpowiedzi na te pytania oraz ustalanie ogólnoludzkich zasad dało początek nowej dziedzinie naukowej, jaką jest bioetyka. Jednym z problemów tej stosunkowo "młodej” nauki jest początek ludzkiego życia, dokonujący się zarówno na płaszczyźnie działań naturalnych, jak i - a może szczególnie - sztucznych ingerencji człowieka. Jest to przedmiotem zainteresowań dwóch zasadniczych sfer naukowej refleksji: biologiczno-medycznej i filozoficzno-teologicznej. Dowodem tego są powstające coraz nowsze opracowania, będące efektem prowadzonych badań empirycznych i refleksji nauk humanistycznych. Zagadnienia te podejmowane są też w ramach studiów, zwłaszcza medycyny i dziedzin filozoficzno-teologicznych. Dokumentowana refleksja naukowo-badawcza stanowi pomoc zainteresowanym tymi zagadnieniami zarówno od strony zawodowej, jak też wszystkim innym, gdyż dotyczy to początków ludzkiego życia. Taką cenną pomoc stanowią dwa fachowe opracowania pani dr n. med. Magdaleny Szymańskiej.

Pierwsza pozycja nosi tytuł Etyczne aspekty rozrodu wspomaganego" (Białystok 2003). W podtytule zapisano, że jest to "Monograficzny skrypt z bioetyki dla studentów medycyny”. Na kolejnych stronicach tekstu Autorka podejmuje szereg bardzo ważnych zagadnień związanych $\mathrm{z}$ dokonywaniem wspomaganego rozrodu. Po „Wstępie” wprowadzającym w całość analiz wyjaśnione zostały podstawowe założenia, cele i zadania bioetyki jako nowej nauki w kontekście współczesnych przemian kulturowych, zwłaszcza w dziedzinie nauk biologiczno-medycznych. Przechodząc do analizy tytułowego problemu, Autorka charakteryzuje metody rozpoznawania płodności kobiet według obserwacji naturalnych objawów płodności i niepłodności kobiety (WHO). Następnie opisuje metody rozrodu wspomaganego (RW), charakteryzując poszczególne etapy pozaustrojowego zapłodnienia. Ta forma prokreacji człowieka została poddana analizie oceniającej, odwołując się do Kodeksu Etyki Lekarskiej oraz innych akt prawnych. Ta etyczno-prawna analiza prowadzi do bioetycznych refleksji nad poczęciem człowieka, dokonywanych w kontekście ustaleń ontologiczno-antropologicznych oraz dyskusji medyków na temat rozrodu wspomaganego osoby ludzkiej. Zostały tu podjęte problemy rozumienia i interpretacji eksperymentu naukowego, definicji i interpretacji stanu ciąży, postawy lekarza wobec pacjenta, zgodności prokreacji z biorytmem płodności i niepłodności, sprzeczności z etosem lekarskim, moralnej dopuszczalności zaleceń lekarskich 
wobec „leczenia niepłodności”, przeanalizowany został problem podmiotowości zarodka i płodu ludzkiego, poszczególne fazy procedury pozaustrojowego zapłodnienia, fakt i znaczenie zespołu poaborcyjnego, inne dylematy bioetyczne towarzyszące rozrodowi wspomaganemu, w tym szczególnie antagonizacja płci oraz powikłania z tym związane. Analizę tego punktu Autorka kończy postawieniem szeregu wątpliwości i pytań natury etycznej. W ostatniej części zatytułowanej „Podsumowanie” M. Szymańska dokonuje zestawienia faktu i procedury wspomaganego rozrodu z zasadami Karty Pracowników Służby Zdrowia wydanej przez Papieską Radę Duszpasterstwa Służby Zdrowia, jak też z ludzkim wymiarem aktu małżeńskiego i prawami dziecka. Zestawienia te pozwalają wskazać argumenty przeciwko eksperymentowaniu na życiu ludzkim, co ma miejsce $\mathrm{w}$ całej procedurze pozaustrojowego zapłodnienia.

Druga $z$ omawianych tu pozycji autorstwa dr. M. Szymańskiej to Bioetyka początków życia (Białystok 2004). Po krótkiej prezentacji problematyki we „Wstępie”, autorka przedstawia problem zatytułowany: „Bioetyczne aspekty diagnostyki prenatalnej". W ramach analiz tego zagadnienia scharakteryzowała obrazową diagnostykę prenatalną, badanie echo, amniopunkcję, biopsję kosmówki, co pozwoliło dokonać etycznej oceny tych działań medycznych w aspekcie godności i obiektywnego dobra osoby ludzkiej. Kolejny punkt nosi tytuł: „Wczesnoporonne działanie antykoncepcji hormonalnej”. Zostały tu omówione: fizjologia hormonalnego cyklu kobiety, mechanizm działania hormonów płciowych, mechanizm działania hormonalnych środków „antykoncepcyjnych”, antykoncepcja hormonalna (inne rodzaje), działanie uboczne hormonalnej antykoncepcji, wczesnoporonne działanie środków antykoncepcyjnych, przeciwwskazania do stosowania antykoncepcji hormonalnej. Działanie te poddane zostały etycznej ocenie uwzględniającej dobro osób biorących udział w poczęciu - małżonków, etyczną wartość aktu płciowego oraz dobro życia dziecka poczętego. Trzecie zagadnienie omawianej książki to: „Metody naturalnego planowania rodziny". Spotykamy tu najpierw opis metod naturalnego planowania rodziny: rozpoznawanie płodności u kobiety (według WHO). Następnie przedstawione zostały zalecenia Światowej Organizacji Zdrowia (WHO) dotyczące naturalnego planowania rodziny oraz nauczanie i poradnictwo w tym względzie z uwzględnieniem ekologicznego karmienia. W dalszej części analiz tego zagadnienia ukazana została historia naturalnego planowania rodziny oraz zalety tego rodzaju metod kierowania płodnością.

Kontynuując swoje analizy prokreacji człowieka, M. Szymańska podejmuje problem: „Etyka wobec medycznie wspomaganej prokreacji”. Najpierw opisuje rozród wspomagany i jego metody od strony medycznej. Następnie zestawia to z normami etycznymi w tym względzie, uwzględniając następujące zagadnienia: etyczny wymiar eksperymentów naukowych, rozumienie i interpretacja stanu ciąży, istotę i znaczenie prokreacji zgodnej z biorytmem płodności i niepłod- 
ności, wpływ zapłodnienia pozaustrojowego na osobowość lekarza, płód jako podmiot, poszczególne fazy procedury pozaustrojowego zapłodnienia, prawa dziecka, zespół poaborcyjny, inne dylematy bioetyczne związane z rozrodem wspomaganym, dobro kobiety w tym działaniu medycznym oraz antagonizacja płci i powikłania z tym związane. Ostatni rozdział omawianej książki nosi tytuł: „Aborcja w ocenie bioetycznej”. Autorka najpierw omawia zjawisko aborcji w wymiarze ogólnoświatowym oraz poszczególne metody niszczenia życia dziecka przed urodzeniem, z podkreśleniem psychospołecznych zaburzeń poaborcyjnych. W dalszej części charakteryzuje badania własne w tym względzie przeprowadzone metodą wywiadu lekarskiego połączonego $\mathrm{z}$ rozmową psychologiczną o charakterze otwartym i zamkniętym. We wnioskach z przeprowadzonych badań stwierdza: „Każda ingerencja w organizm kobiety którą jest przerwanie ciąży, wcześniej czy później może przyczynić się do różnych konsekwencji fizycznych, psychicznych i duchowych" (s. 77). Charakteryzując te objawy i następstwa wyróżnia dwa podstawowe: rozpacz [PAD] i syndrom poaborcyjny [PAS]. Poza tymi skutkami, które dotyczą kobiet - matek, podkreślono też wpływ aborcji na: dzieci w rodzinie, na obojga rodziców, jak też na personel medyczny. W ostatniej części ukazane zostało leczenie i sposoby terapii osób dotkniętych skutkami aborcji oraz etyczna ocena działań poszczególnych osób biorących udział w tym niszczeniu życia poczętego.

Przedstawione tu dwie pozycje dr M. Szymańskiej stanowią cenne opracowania $\mathrm{z}$ dziedziny bioetyki i godne są polecenia nie tylko zainteresowanym niejako „zawodowo" tymi problemami. Na podkreślenie zasługuje wiele aspektów tych książek. Już sama aktualność podjętych tam zagadnień jest godna uwagi. Wiadomo, że we współczesnej kulturze życia toczy się dynamiczny spór, a właściwie walka o początek ludzkiego życia: istotę bytu osobowego, czas początku człowieka, sposób poczęcia i ochronę życia poczętego. Właściwie wszystkie te zagadnienia znajdują miejsce $\mathrm{w}$ omawianych książkach i zostały poddane fachowej analizie. Te dwa opracowania, choć w skrótowej formie, stanowią swoiste kompendium wiedzy medyczno-etycznej na temat początków życia człowieka. Autorka - jako lekarz ginekolog - wykorzystując najnowszą wiedzę medyczną, poddaje analizie najbardziej podstawowe od strony medycznej, ale też szczególnie newralgiczne od strony etycznej, problemy związane z poczęciem człowieka i jego rozwojem płodowym. Można bez obawy przesady powiedzieć, że omawiane tu pozycje stanowią kompendium wiedzy medyczno-etycznej dotyczącej początków ludzkiego życia.

Lektura omawianych opracowań dr M. Szymańskiej przekonuje nie tylko o aktualności podjętej tu problematyki. Jeszcze większą wartość stanowi merytoryczna dojrzałość analiz Autorki. Na pierwszym miejscu chciałbym podkreślić medyczny wymiar owych analiz, co jest szczególnie ważne wszystkim zajmującym się bioetyką, a nieposiadającym fachowego przygotowania medycznego 
czy biologicznego. W prezentowanych tu książkach spotykamy bardzo cenne, analitycznie pogłębione przedstawienie praktycznie wszystkich procesów biologiczno-medycznych zachodzących przy poczęciu człowieka. Ukazany został zarówno naturalny przebieg owych procesów, jak też ich deformacje oraz związane z tym zagrożenia zdrowia czy życia człowieka. Na kanwie tego zostały przedstawione sposoby i skutki działania medycznego oraz stosowanych środków chemicznych, ze wskazaniem właściwych im konsekwencji. Z całym naciskiem należy podkreślić, że w literaturze medycznej właściwie do rzadkości należy tego typu opracowanie, gdzie w sposób rzetelny od strony badawczej ukazane zostały faktyczne skutki zewnętrznej medyczno-biologicznej interwencji w poczęcie ludzkiego życia i okres jego prenatalnego rozwoju. Autorka, w oparciu o wiedzę i doświadczenie medyczne, oraz jako odpowiedzialny nauczyciel akademicki niezwykle kompetentnie ukazuje przebieg kolejnych faz i sposobów owej „pomocy” oraz medyczny efekt owego wkraczania w naturalny proces początków ludzkiego życia. Takie ukazanie tych niezwykle ważnych, ale też trudnych działań ludzkich, daje możliwość - nawet mało znającym problematykę medyczną - zrozumienia istoty owych „wspomagających zabiegów”, a w dalszej konsekwencji wyrobienia własnej ich oceny.

Merytoryczno-metodologiczną wartość omawianych opracowań wzmacnia fakt, że dr M. Szymańska w swych analizach odwołuje się do bogatej literatury polskiej i światowej. Pozwala to czytelnikowi zapoznać się z bogatym fachowym piśmiennictwem na dany temat, a tym samym utwierdzić się w słuszności sposobu podejścia do omawianych zagadnień. W konsekwencji, jeszcze bardziej przekonuje to o słuszności wniosków, do jakich Autorka dochodzi. Żeby jeszcze bardziej uwiarygodnić zarówno przeprowadzone analizy, jak i końcowe wnioski, M. Szymańska ukazuje też początki i historyczno-kulturowy kontekst rozwoju omawianych działań medyczno-biologicznych. Pozwala to zrozumieć przyczyny i uwarunkowania powstawania i rozwijania różnych form interwencji w proces początków ludzkiego życia. Poznanie owych historyczno-kulturowych okoliczności „wspomagania” ludzkiego rozrodu daje możliwość rozpoznania faktycznych intencji badań nad początkami ludzkiego życia oraz wkraczania w jego naturalny rozwój. Czytelnik może się przekonać, że często nie chodziło tu o dobro człowieka poczętego lub mającego być poczętym (nasciturus), czy też dobro rodziców owego dziecka. Wielokrotnie też owe badania i działania medyczne tylko ubocznie wspomagają tego, do którego w swym tytule badawczym się odnoszą. Inaczej mówiąc, widać tu zwykłe zakłamanie zarówno w samych quasi-naukowych badaniach, jak też w prezentacji ich skutków dla osób zainteresowanych. Istotę tego typu intencji i zamierzeń dobrze ukazują prezentowane opracowania dr. M. Szymańskiej.

W omawianych pozycjach mamy też fachową interpretację i ocenę etyczną przedstawianych działań biologiczno-medycznych. Autorka prezentuje anali- 
tyczne podejście do poszczególnych zagadnień, rozważa wszelkie „za” i „przeciw”, wnioski zaś popiera poważnymi opracowaniami z fachowej literatury przedmiotu. Widać w tym niezwykle odpowiedzialne podejście do podejmowanych problemów, troskę o możliwie całościowe spojrzenie na dane zagadnienie, oraz jasne przedstawienie motywów i racjonalnych podstaw prezentowanej oceny etycznej. Takie podejście do trudnych i skomplikowanych problemów zasługuje na jak największe uznanie, co też podkreślają recenzenci. Profesor zw. dr hab. n. med. M. Troszyński, specjalista ginekolog-położnik, w swojej „Przedmowie” do Bioetyki początków życia stwierdza: „Tekst ten powinien być szeroko rozpropagowany wśród młodzieży” (tamże, s. 5). Podzielając opinię pana Profesora, wyrażam życzenie, aby te dwie omawiane pozycje doczekały się ponownego - może łącznego - wydania. Z pewnością będą służyć pomocą, ubogacając wiedzę i kształtując odpowiedzialne postawy wobec ludzkiego życia nie tylko młodzieży, ale każdego człowieka, który zainteresowany jest prawdziwym dobrem osoby.

Ks. Józef Zabielski Uniwersytet $w$ Bialymstoku 